\title{
Spatial analysis of rockfall activity, bounce heights and geomorphic changes over the last 50 years - A case study using dendrogeomorphology
}

\author{
D.M. Schneuwly *, M. Stoffel \\ Laboratory of Dendrogeomorphology, Department of Geosciences, University of Fribourg, Chemin du Musée 4, 1700 Fribourg, Switzerland
}

\begin{abstract}
Tree-ring series have been used to reconstruct 50 years of rockfall behavior on a slope near Saas Balen (Swiss Alps). A total of 796 cores and 141 cross sections from 191 severely injured conifer trees (Larix decidua Mill., Picea abies (L.) Karst. and Pinus cembra L.), combined with a series of aerial photographs, were used to investigate the evolution of the forest stand so as (i) to reconstruct past rockfall rates; (ii) to analyze the spatial behavior of maximum bounce heights; and (iii) to analyze the spatial comportment of rockfall activity over the last five decades.

Tree-ring analysis permitted the reconstruction of the age distribution at the study site; results were in perfect agreement with the afforestation process shown in the aerial photographs. The oldest are located in the lower, central part of the study site; the youngest individuals at its uppermost lateral boundaries. Reconstructed rockfall rates reveal strong interannual variations and single event years with increased activity, namely in 1960/1961 and 1995. Spatial analysis of the maximum bounce heights indicate highest values at the lateral boundaries and lowest heights in the lower central part of the forest stand, where a big boulder seems to shield trees growing below it. The spatial analysis of past rockfall activity shows high active zones at the uppermost north-facing boundaries of the forest and least active zones in the lowermost central part of the studied stand. The high rockfall activity at the slope is expressed by a mean rockfall rate of $>1$ event $\mathrm{m}^{-1} \mathrm{y}^{-1}$.
\end{abstract}

Keywords:

Dendrogeomorphology

Tree-ring

Rockfall

Spatial analysis

Frequency

GIS

\section{Introduction}

Rockfall is one of the most common mass movement processes in mountain regions and is defined as the free falling, bouncing or rolling of individual or a few rocks and boulders, with volumes involved generally being $<5 \mathrm{~m}^{3}$ (Berger et al., 2002). As rockfall potentially endangers humans and infrastructure, it has become one of the most intensely studied geomorphic processes of the cliff zone in mountain areas.

Therefore, numerous studies exist concerning various aspects of rockfall, such as the dynamic behavior (Ritchie, 1963; Erismann, 1986; Azzoni et al., 1995), boulder reaction during ground contact (Bozzolo and Pamini, 1986; Hungr and Evans, 1988; Evans and Hungr, 1993), or runout distances of falling rocks (Kirkby and Statham, 1975; Statham and Francis, 1986; Okura et al., 2000). Much research was also done on the possible triggers of rockfall, such as freeze-thaw cycles (Gardner, 1983; Matsuoka and Sakai, 1999; Matsuoka, 2006), changes in the rock-moisture level (Sass, 2005), the thawing of permafrost (Gruber et al., 2004), the increase of mean annual temperatures (Davies et al.,

\footnotetext{
* Corresponding author. Tel.: +41 2630090 19; fax: +41 263009746. E-mail address: dominique.schneuwly@unifr.ch (D.M. Schneuwly).
}

2001), tectonic folding (Coe and Harp, 2007) or the occurrence of earthquakes (Harp and Wilson, 1995; Marzorati et al., 2002). In addition, several studies exist on the long-term accretion rates of rockfall (Luckman and Fiske, 1995; McCarroll et al., 1998). Furthermore, since the late 1980s, the field of numeric modelling has become a major topic in the field of rockfall research (Zinggeler, 1989; Guzzetti et al., 2002; Dorren et al., 2006; Stoffel et al., 2006).

However, there are only a few studies that analyze the temporal evolution of rockfall. Some observation-based studies were conducted over one or several summers (Luckman, 1976; Douglas, 1980; Gardner, 1980), yielding valuable data on the contemporary activity, but major difficulties were encountered in estimating long-term changes in rockfall accretion rates. Douglas (1980), for example, performed detailed observations of rockfall in Co. Antrim, Ireland, on a weekly basis and over a period of two years. Results indicate seasonal peaks of rockfall activity in February and March, as well as in November and December, and a constant but small background activity during the rest of the year. More recently, Sass (2005) installed more than 60 rockfall barriers in the Bavarian Alps so as to quantify rockfall activity over a period of four years. He concluded that the distribution of rockfall is highly variable in time and that it is triggered by a combination of a multitude of parameters. 
While these in situ observations provide detailed data sets on short periods of time, they are, however, too limited for revealing trends or years with above-average activity. Luckman and Fiske (1995) used lichens to estimate rockfall rates for the last 300 years, but could only deliver a spatial resolution of 50 years; while McCarroll et al. (1998) estimated rockfall rates for the late Holocene with a temporal resolution of 25 years using lichenometry.

In a similar way, only a few studies exist that reconstruct the spatial behavior of rockfall on a slope. Gardner (1980) used a spatial grid of $500 \mathrm{~m}$ during his fieldwork, rendering detailed spatial analysis impossible. Luckman and Fiske (1995) worked on two different sectors of one large talus slope, but did not look at spatial variations between or within the areas.

In contrast to other mass movement processes (Shroder, 1978, 1980; Wiles et al., 1996; Solomina, 2002), tree-ring analyses have only rarely been used in rockfall research. Lafortune et al. (1997) reconstructed sedimentation rates on a scree slope by analyzing tree-rings. Several recent studies have been conducted using tree-ring analyses so as to investigate different rockfall aspects, namely in assessing seasonal timing (Stoffel et al., 2005a; Schneuwly and Stoffel, 2008 ) or to investigate the evolution of rockfall over time (Stoffel et al., 2005b). Stoffel et al. (2005b) used a new approach to investigate combined spatial and temporal variations of rockfall. They analyzed 135 trees severely injured by rockfall to reconstruct historic rockfall rate with its spatial behavior. As the $\sim 800$ growth anomalies covered four entire centuries (1600-2002), the rockfall rate had to be reconstructed on a decadal basis to provide a reliable data set. In addition, the spatial distribution is not necessarily representative of the present-day behavior of rockfall activity at the study site.

It is therefore the aim of this study to use dendrogeomorphological methods to (i) investigate the evolution of the Schilt forest in the Valais Alps (Switzerland); (ii) determine yearly rockfall rates; and (iii) analyze the spatial behavior of rockfall aspects. Results were obtained from 937 samples of 191 European larch (Larix decidua Mill.), Norway spruce (Picea abies (L.) Karst.), and Swiss stone pine (Pinus cembra L.) trees on an homogenous rockfall slope, thus providing a very dense data set of more than 2050 growth disturbances resulting from rockfall activity over the last five decades.

\section{Study area}

The study site is situated in the "Schilt" forest near Saas Balen ( $46^{\circ} 09^{\prime} 06^{\prime \prime}$ N., $7^{\circ} 55^{\prime} 27^{\prime \prime}$ E.) in the Valais Alps, Switzerland (Fig. 1). The forest stand investigated is located between 1390 and $1610 \mathrm{~m}$ asl on the ENE-facing slope below the Lammenhorn (3189 $\mathrm{m}$ asl). The bedrock in the zone of origin consists of micaceous schists belonging to Penninic crystalline layers, dipping SSE with an angle of ca. $20^{\circ}$ (Bearth, 1973, 1980). Rockfall frequently occurs on the slope, originating from the disintegrated and glacially oversteepened cliffs at 1750-1900 m asl (Fig. 2). Quaternary talus and morainic deposits cover the transition and deposition zones.

Archival data and local toponomy indicate the occurrence of rockfall in the region since at least the early eighteenth century when rockfalls descended from the neighboring "Steinschlagwald" (=rockfall forest) and destroyed the old parish church (Ruppen et al., 1979). In contrast, other mass movement processes, such as debris flows or snow avalanches, have never been witnessed on the slope.

The volume of falling rocks does not normally exceed $1 \mathrm{~m}^{3}$ on the study site. However, few blocks are deposited in the valley bottom with volumes of up to $50 \mathrm{~m}^{3}$, bearing witness to major events in the past. In addition, the largest block on the entire slope, unique in its kind, is located at the uppermost end of the investigated area and has an estimated volume of $2000 \mathrm{~m}^{3}$.

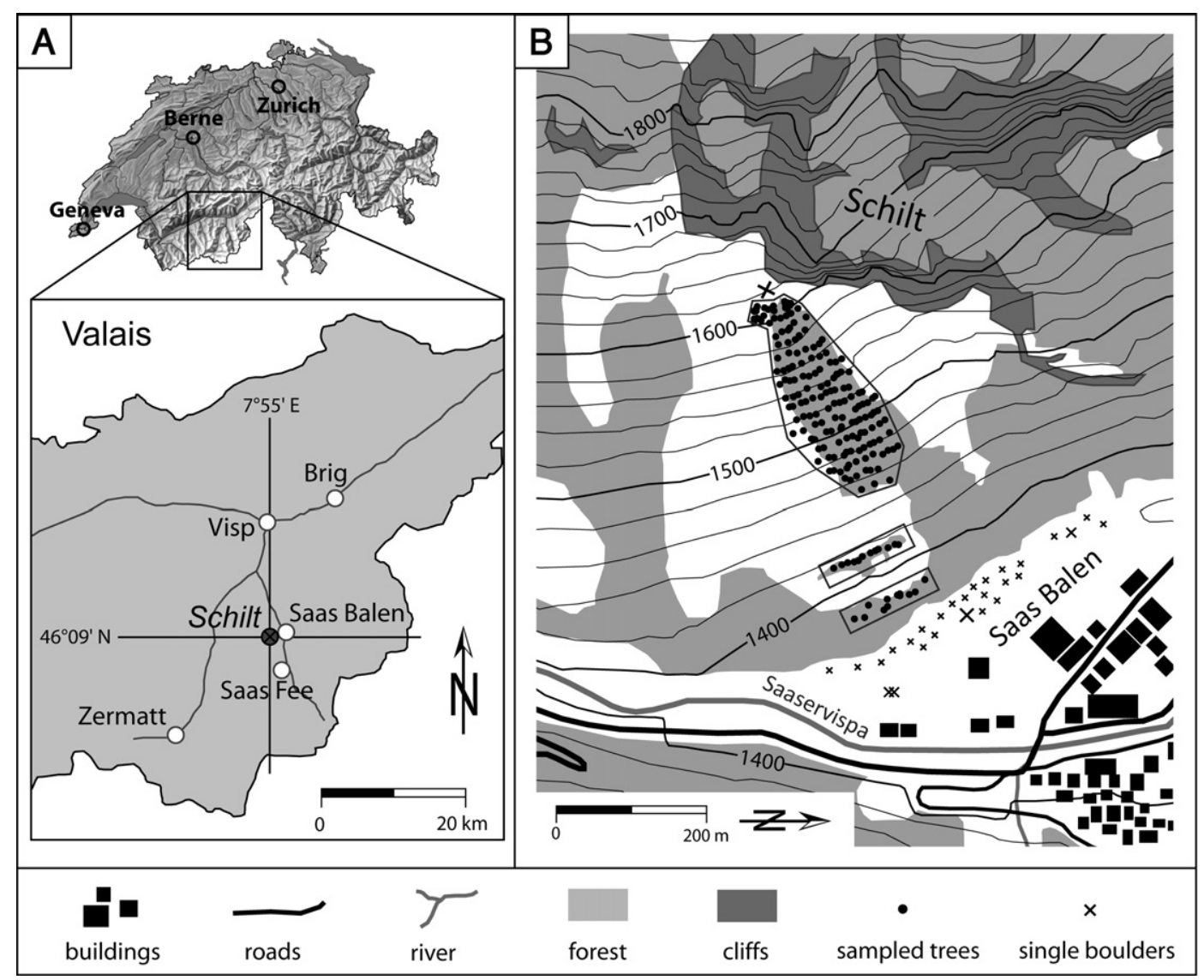

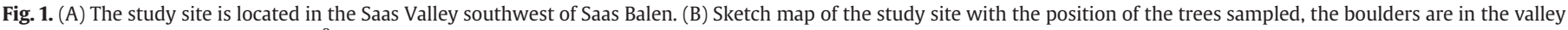
bottom and the large block $\left(2000 \mathrm{~m}^{3}\right)$ is at the top of the study site. 


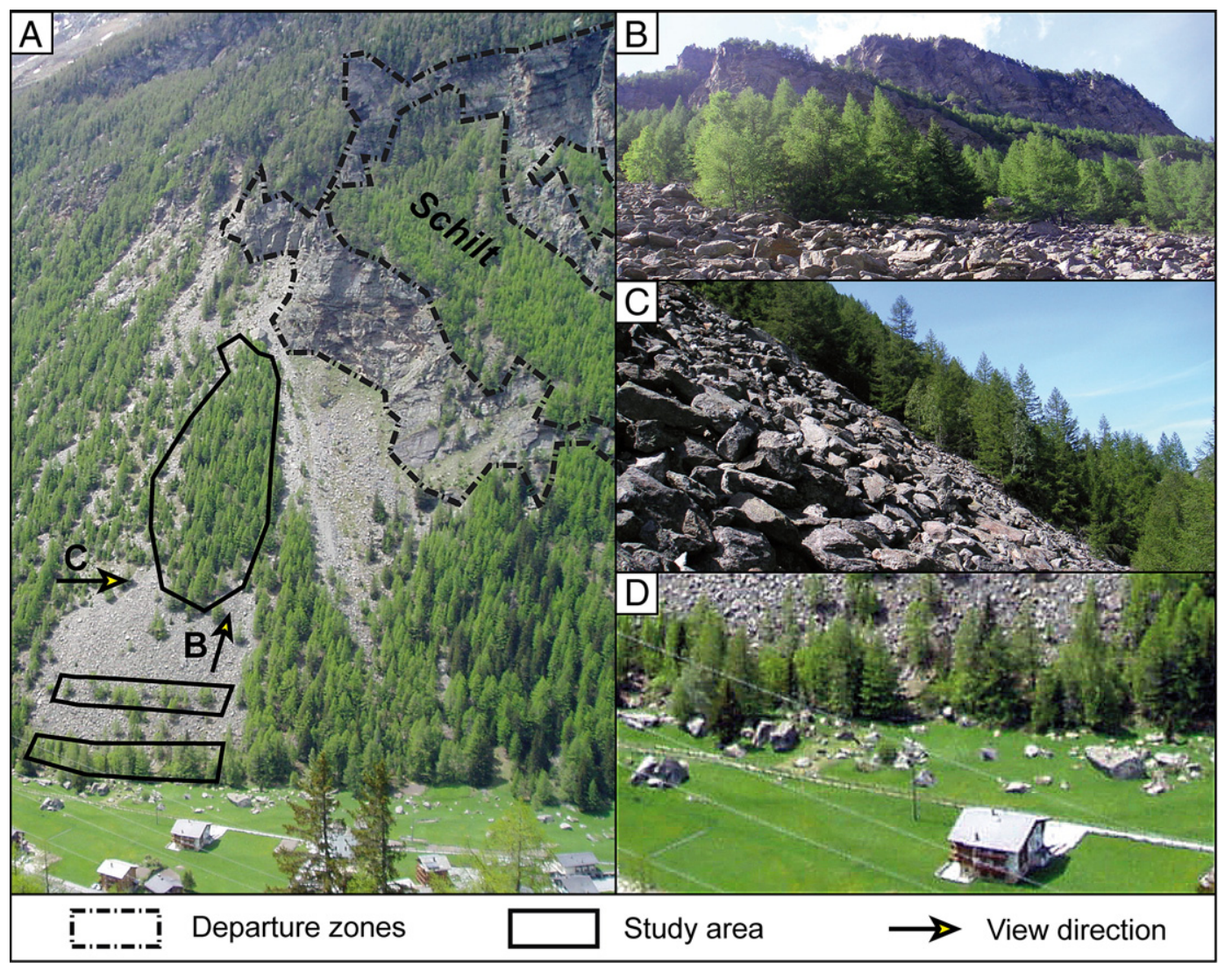

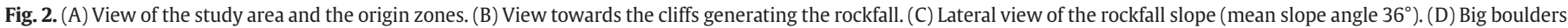
in the valley bottom bearing witness to major Holocene rockfall events.

The study site is $300 \mathrm{~m}$ long and has an average width of $75 \mathrm{~m}$, covering a surface of $\sim 20,000 \mathrm{~m}^{2}$. The mean slope angle is $36^{\circ}$ with only a small variation between the top and the bottom of the study site. A centimetric soil layer covers rockfall deposits within the study site, whereas the surfaces outside the study area remain almost free of vegetation and are covered with bare rocks and boulders. The stand at Schilt mainly consists of Larix decidua Mill. trees (90\%), of some Picea abies (L.) Karst. (10\%), and single Pinus cembra L. (<1\%). Three separate forest units exist; the largest located in the upper half of the site is covered with a stand that becomes gradually denser towards its upper limits. The two other units each consist of small forested bands oriented perpendicular to the fall line and are located at the bottom of the investigated area. Between the largest unit and the first band there is a distance of $60 \mathrm{~m}$. The gap between the first ( $1390 \mathrm{~m}$ asl) and the second forest band ( $1410 \mathrm{~m}$ asl) is $40 \mathrm{~m}$. No anthropogenic influence is visible in the forest stand, either at the study site itself or in neighboring forested sectors.

\section{Material and methods}

\subsection{Sampling strategy}

At the study site, virtually all of the trees show clearly visible and severe growth disturbances (GD) caused by past rockfall events in the form of scars, broken crowns or branches, and tilted stems, with scars being the most prominent sign of previous rockfall activity in the predominantly young trees. As scars represent the most accurate and reliable GD to date past rockfall events (Schneuwly and Stoffel, 2008), we focused sampling exclusively on the analysis of wounds. Sampling was performed along horizontal transects in order to investigate the entire stand and to assure an even distribution of trees throughout the study site. Transects were chosen every $15 \mathrm{~m}$, and one tree was selected every $10 \mathrm{~m}$ along each transect. As the use of GPS devices was not possible with precision in the steep valley and within the forest at "Schilt", the positioning of the selected trees on the map was based on aerial photographs and using a measuring tape.

Sampling of trees was undertaken using two different methods: (i) on one hand, we used a small handsaw to obtain entire cross sections from each injury of trees with a basal diameter $<15 \mathrm{~cm}$; (ii) on the other hand, we extracted cores (max. $40 \mathrm{~cm} \times 5 \mathrm{~mm}$ ) with increment borers. Injuries in bigger trees $(<15 \mathrm{~cm})$ were sampled with at least one core per scar, with the core extracted from the overgrowing tissue at a height showing the maximum wound extension. As the extraction of cores from the overgrowing callus needs to be effected at the contact of the injured with the non injured tissue, normally more than one sample had to be taken to obtain adequate core samples.

In addition, data recorded for each tree included micro topography or the accumulation of rockfall deposits in the immediate vicinity of the tree. We also noted tree-specific data including specie, height, diameter at breast height (DBH), and comments on neighboring trees. All visible defects in its morphology (such as scars (direction, surface and height of centre above ground level), broken crowns or branches, and tilted stems or candelabra growth) were recorded and general pictures of the tree and for each wound were taken to facilitate rockfall reconstruction in the laboratory. In a final step and in case any increment cores were taken, we noted the height and direction of each core sample.

\subsection{Tree-ring analysis}

The disturbed tree samples were analyzed using standard dendrochronological methods (Stokes and Smiley, 1968; Bräker, 2002). The samples were first polished and the tree rings counted, before tree-ring series were analyzed visually to identify GD caused by past rockfall. Among the different reactions, we focused on the 
Table 1

Absolute and relative numbers of sampled species, their localization, and sampling method

\begin{tabular}{lrr}
\hline & Number of trees & $\%$ \\
\hline Trees sampled & 176 & 92.2 \\
L. decidua & 14 & 7.3 \\
P. abies & 1 & 0.5 \\
$P$. cembra & & \\
Forest stand & 167 & 87.4 \\
$\quad$ Main forest stand & 24 & 12.6 \\
Small forest bands & & \\
Sampling method & 161 & 84.3 \\
$\quad$ Increment borer & 30 & 15.7 \\
$\quad$ Handsaw & &
\end{tabular}

occurrence of tangential rows of traumatic resin ducts (TRD; Bollschweiler et al., 2008; Schneuwly and Stoffel, 2008; Stoffel, in press), the presence of callus tissue (Schweingruber, 2001), eccentric growth and the formation of compression wood (Braam et al., 1987a; Fantucci and Sorriso-Valvo, 1999), as well as abrupt changes in growth (Strunk, 1997; Friedman et al., 2005).

Within this study, we primarily focused on the formation of resin ducts, although they may have causes other than rockfall, e.g., climatic stress, high winds, insect attack, or fraying and cropping by ungulates. However, as sampling was performed exclusively next to visible wounds, we can be certain that all TRD present on the cores were the result of disturbances caused by falling rocks. Nevertheless, to assure a well-defined classification, we applied the limitations defined by Stoffel et al. (2005b), who only considered resin ducts to be the result of rockfall activity if they were (i) traumatic, (ii) extremely compact, and (iii) forming continuous rows.

Callus tissue is formed after cambium damage (Schweingruber, 1996, 2001). It occurs primarily at the borders of rockfall injuries (Stoffel et al., 2005a,b; Perret et al., 2006) and had to be clearly present to be taken into account.

In case several cores of a single tree showed TRD in the same year, they were considered as one single event, as the injuries could have been caused by the same event or even the same rock. In case several TRD were present on a single core in different years, the latter were only considered if there were thought to be at least five undisturbed years between the two occurrences. Consequently, results presented in this study have to be considered as minimum frequencies.

Following the ideas of Braam et al. (1987b), reaction wood was only considered if the growth change was sudden and over a period of five or more years. Finally, ring widths were analyzed visually so as to identify abrupt changes in growth following impacts (decrease or increase; Schweingruber, 1996, 2001).

In addition, the chance of identifying rockfall scars in trees increases with a rising number of trees on one hand and with the continuous diameter growth of trees on the other hand. In this sense, a thick stem exposes a larger target to falling rocks and is more easily struck than a smaller one. Per Stoffel et al. (2005b), we therefore used a rockfall "rate" expressed as the number of rockfall events per meter width of all tree surfaces (DBH sum) present per year so as to be able to compare present with past rockfall activity. To assess the annual rockfall rate, the DBH increment of every individual tree per year was determined by dividing its DBH by the number of rings between pith and sample year (2006) at breast height. The DBH values of all trees existing at the beginning of a particular year were then summarized to include what we refer to as exposed diameter (ED; in $\mathrm{m}$ ). To obtain the rockfall "rate", the yearly sum of reconstructed events was finally divided by the ED, indicating the number of events recorded per meter ED and per year.

In order to investigate the spatial behavior of rockfall activity, the rockfall rate at the position of each tree had to be calculated. Therefore, the average DBH of each individual was assessed as a first step by dividing its DBH by two, resulting in a simplified mean ED per tree. This mean ED was then multiplied by the age of the tree, producing the cumulative ED of each tree. Finally, the number of events per tree was divided by its cumulative ED so as to calculate the number of events $\mathrm{m}^{-1} \mathrm{y}^{-1}$.

\subsection{Spatial visualization of tree-ring data}

The general evolution of the forest stand at the entire study site was first investigated with six aerial photographs taken in different years (1941, 1958, 1968, 1981, 1993, and 2004). The pictures were initially georeferenced and then visually analyzed.

However, only the large stand in the upper half of the study site was investigated in detail with geographic information systems GIS as the spatial relationship between this stand and the two small forest bands farther below was too weak. Data used on single trees included their position, age, maximum injury heights, number and year of events, and DBH. In order to allow spatial visualization of the data in a GIS, tree coordinates were transformed into geo-objects and linked to their attributes from the database. Data elements were investigated with the Geostatistical Analyst extension (ESRI, 2008a) from the ESRI ArcGIS software (ESRI, 2008b) to examine spatial relationships between all sample points.

Following the procedure described in Johnston et al. (2003), skewed data were normalized as a first step. Trend analyses were then performed to identify directional influences (global trends), and data afterwards detrended using first- or second-order polynomials. Next, spherical semivariogram models and covariance clouds were used to analyze spatial autocorrelation and to adapt the number of lags and bin sizes. Cross validation of the measured points with the predicted points finally allowed the determination of mean prediction errors of the applied model. After consideration of the data, the Ordinary Kriging model (Johnston et al., 2003) was chosen for visualization of the continuous surfaces. We reviewed data from the five closest trees and at least two individuals for each of the four angular sectors to perform the interpolations for every single point in the interpolation sector.

\section{Results}

\subsection{General aspects}

In total, 191 trees were investigated in 19 horizontal transects, and the height and surface of 650 well-defined rockfall injuries were measured. As can be seen from Table 1, the large majority of sampled trees were $L$. decidua (92.2\%), whereas P. abies only accounted for $7.3 \%$. $P$. cembra trees are scarce on the slope and only one individual was sampled for analysis: 167 trees (87.4\%) were sampled along the 17 transects in the main forest stand, and 24 (12.6\%) individuals were selected in the two horizontal forest bands located farther down (i.e. 12 trees per transect). Among the selected trees, 161 (84.3\%) were sampled with increment borers, and 30 (15.7\%) smaller individuals were felled with a handsaw. In total, 937 samples were chosen for

\section{Table 2}

Number of samples, growth disturbances (in absolute and relative numbers), and reconstructed events identified on increment cores and cross sections

\begin{tabular}{lclrl}
\hline & Number & $\%$ & Cores & Cross sections \\
\hline Samples & 937 & & 796 & 141 \\
Number of growth disturbances & 2057 & 100 & 1656 & 401 \\
Injuries & 332 & 16.1 & 153 & 179 \\
Traumatic resin ducts & 1221 & 59.4 & 1028 & 193 \\
Growth suppression & 229 & 11.1 & 210 & 19 \\
Growth release & 56 & 2.7 & 55 & 1 \\
Callus tissue & 206 & 10 & 201 & 5 \\
Compression wood & 13 & 0.6 & 9 & 4 \\
Reconstructed events & 755 & & 647 & 108 \\
\hline
\end{tabular}


analysis, namely 796 increment cores and 141 cross sections (Table 2). Tree age averaged 35.7 years (STDEV: 16.7 years), with the oldest tree showing 96 and the youngest only 12 increment rings. Tree age of the main forest averages 32.1 years, whereas the individuals situated in the two small forest bands are older with 53.1 (upper band) and 68.5 (lower band) years, respectively.

\subsection{Evolution of the stand and age distribution of trees}

The analysis of the time series of aerial photographs covers the last 66 years of forest evolution on the study site. In 1941 (Fig. 3A), most surfaces of the investigated area were free of vegetation and the only trees existing were found in the lowermost part of the study site close to the bottom of the valley. Aerial photographs from 1981 (Fig. 3B) and 2004 (Fig. 3C), in contrast, illustrate the constant colonization of the study area with trees from the lower levels upward.

Tree-ring based data (Fig. 3D) confirm the age distribution and provide a more detailed picture of the afforestation history of the stand. It can clearly be seen that the oldest trees ( $>40$ years) are clustered in the central lower part of the main forest stand. Towards the lateral borders of the stand, trees become gradually younger, with the youngest being identified at the upper end of the stand (average age of $<20$ years).

\subsection{Bounce heights of rocks}

In the field, the impact heights of the 650 injuries were recorded and grouped into classes of $20 \mathrm{~cm}$. As can be seen from Fig. 4, injury heights show a normal distribution with an average impact height located at $8 \mathrm{~cm}$ (SDTEV $6 \mathrm{~cm}$ ). Most injuries (106 hits, 17\%) were observed between 40 and $6 \mathrm{~cm}$ above ground level. More than twothirds (67.4\%) of all injuries were below $1 \mathrm{~m}$, and only 22 scars (3.4\%) were located above $2 \mathrm{~m}$, with the highest injury identified at $4.5 \mathrm{~m}$.

The spatial analysis and representation of maximum bounce heights of falling rocks was based on the uppermost injury per tree.

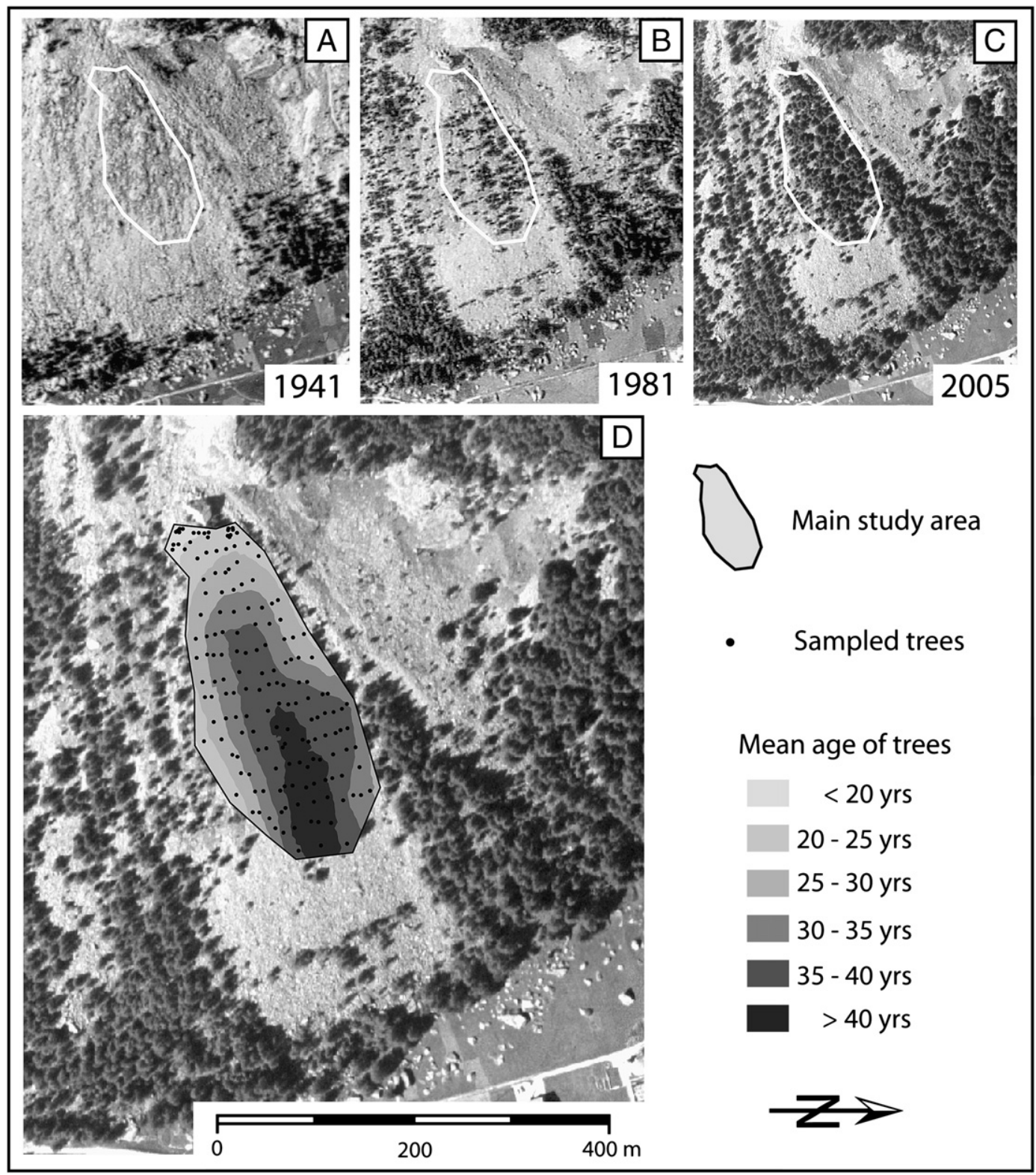

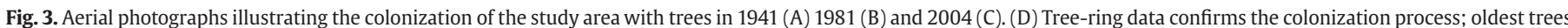

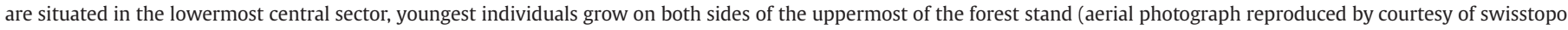
(BA081119)). 


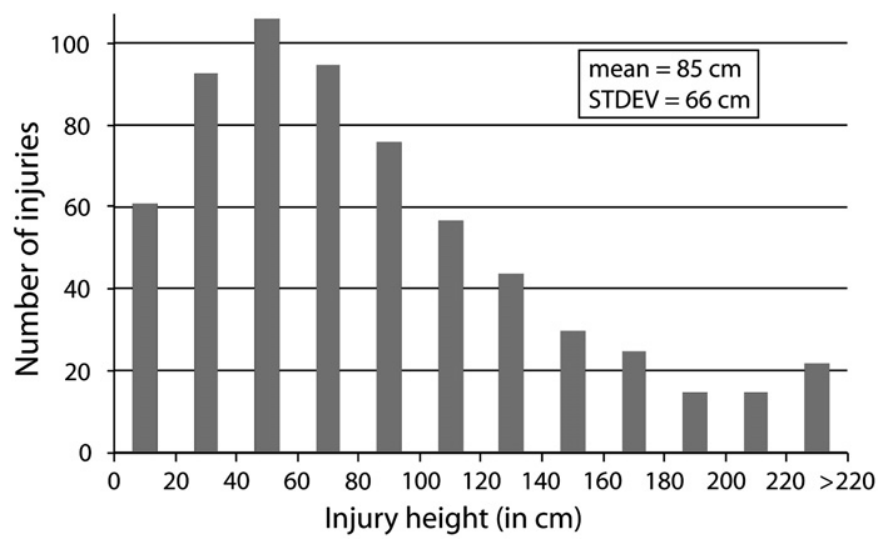

Fig. 4. Injury height distribution with a mean of $85 \mathrm{~cm}$ and a maximum of $450 \mathrm{~cm}$.

The average maximum bounce height per tree for the entire stand is $126 \mathrm{~cm}$ for the entire slope and it accounts for $121 \mathrm{~cm}$ in the interpolated area (i.e., the main stand). As illustrated in Fig. 5, the spatial distribution of maximum bounce heights clearly indicates that the lowest values $(<8 \mathrm{~cm})$ are observed in the uppermost central part of the site where a huge boulder deviates or even halts rockfall. For the same reason, comparably low values are also observed farther down in the central sector where, in addition, the large number of neighboring trees has a certain shielding effect. In contrast, bounce heights become increasingly important towards the lateral boundaries of the forest stand, resulting in maximum average bounce heights $>2 \mathrm{~m}$ in the southernmost segment of the study site.

\subsection{Growth disturbances (GD) in trees affected by rockfall}

In total, the analysis of the 937 samples allowed identification of 2057 GD and reconstruction of 775 rockfall events, resulting in an average of 3.95 events per tree and a mean recurrence interval of 9.0 years. As can be seen from Table 2, 332 injuries, or $16.1 \%$ of all GD, were directly visible on the samples (mainly on the cross sections). The most frequent GD observed were, however, tangential rows of traumatic resin ducts (TRD), which occurred 1221 times and represent $59.4 \%$ of all GD. Abrupt growth suppression was observed on 229 occasions (11.1\%), whereas abrupt growth release could only be identified in 56 cases (2.7\%). Callus tissue was present 206 times (10\%), mostly in the segments of the rings bordering injuries. Finally, compression wood was only rarely present on the samples (13 cases; $0.6 \%)$.

\subsection{Rockfall frequency, event years, and spatial distribution of activity}

During the early colonization stage of the investigated forest stand, the number of samples was too small to allow comparisons of past events and recent evolution of the rockfall activity. We therefore limited the reconstruction to the last 50 years (1957-2006), thus reducing the number of injuries to 745 .

Rockfall activity on the slope is expressed as a rockfall "rate" and varies from zero to more than 6 events $\mathrm{m}^{-1} \mathrm{y}^{-1}$, with an average of 1.02 events $\mathrm{m}^{-1} \mathrm{y}^{-1}$ between 1957 and 2006 (STDEV: 1.2 events $\mathrm{m}^{-1} \mathrm{y}^{-1}$ ). As Fig. 6 illustrates, years with "no activity" are concentrated in the early colonization period when fewer trees were present for analysis. The last year with apparently no GD in the tree-ring series is noted in 1966. The absence of events in the early years occurred when the total diameter of all trees at breast height (DBH) was still low $(2.3 \mathrm{~m}$ in 1957), whereas the exposed diameter of all investigated trees accounts for $38.2 \mathrm{~m}$ today. While the DBH increase was rather exponential between the 1950s and late 1980s, it became more gradual over the last 20 years.
As for event years, we observe several years with important rockfall activity in $1960,1961,1978$, and 1995 . In 1960 , the rockfall rate attained 3.9 events $\mathrm{m}^{-1}$ and culminated in 6.6 events $\mathrm{m}^{-1}$ in the following year (1961), thus exceeding the average by a factor of 6.5. A less pronounced peak occurred in 1978 with a rockfall rate of 2.5. The latest peak in rockfall activity is noted for 1995, when 5.1 events $\mathrm{m}^{-1}$ were reconstructed from the tree-ring series. The 7-year moving average displayed in Fig. 6 does not show any significant trend in rockfall activity and is primarily influenced by the years with important rockfall activity in the early 1960s and in 1995.

Concerning spatial patterns, the highest rockfall activity can be observed at the lateral boundaries of the stand. The north-facing forest edge, pointing towards the main rockfall source area in a northwestern direction, shows the highest activity with more than 4 events $\mathrm{m}^{-1} \mathrm{y}^{-1}$. In contrast, much less activity seems to be in the central area of the lowermost part of the study site, as trees are protected by their neighbors growing further above in the stand. The rockfall rate in the least active areas does not even attain 0.75 events $\mathrm{m}^{-1} \mathrm{y}^{-1}$ (see Fig. 7).

\section{Discussion}

In the present study, 191 tree-ring series from Larix decidua Mill., Picea abies (L.) Karst., and Pinus cembra L. were investigated to reconstruct rockfall behavior over the last 50 years. In total, 796 cores and 141 cross sections were analyzed, yielding data on 937 samples. Based on the anatomy of the scars (i.e. tangential rows of traumatic resin ducts, presence of callus tissue, eccentric growth, formation of compression wood and abrupt changes in growth), 2057 GD were determined for these samples, resulting in 755 reconstructed events. Trees with a DBH $>15 \mathrm{~cm}$ were exclusively sampled with increment borers. As the sampling was performed as close as possible to the wounds, GD were in general well pronounced and could be detected without any difficulty.

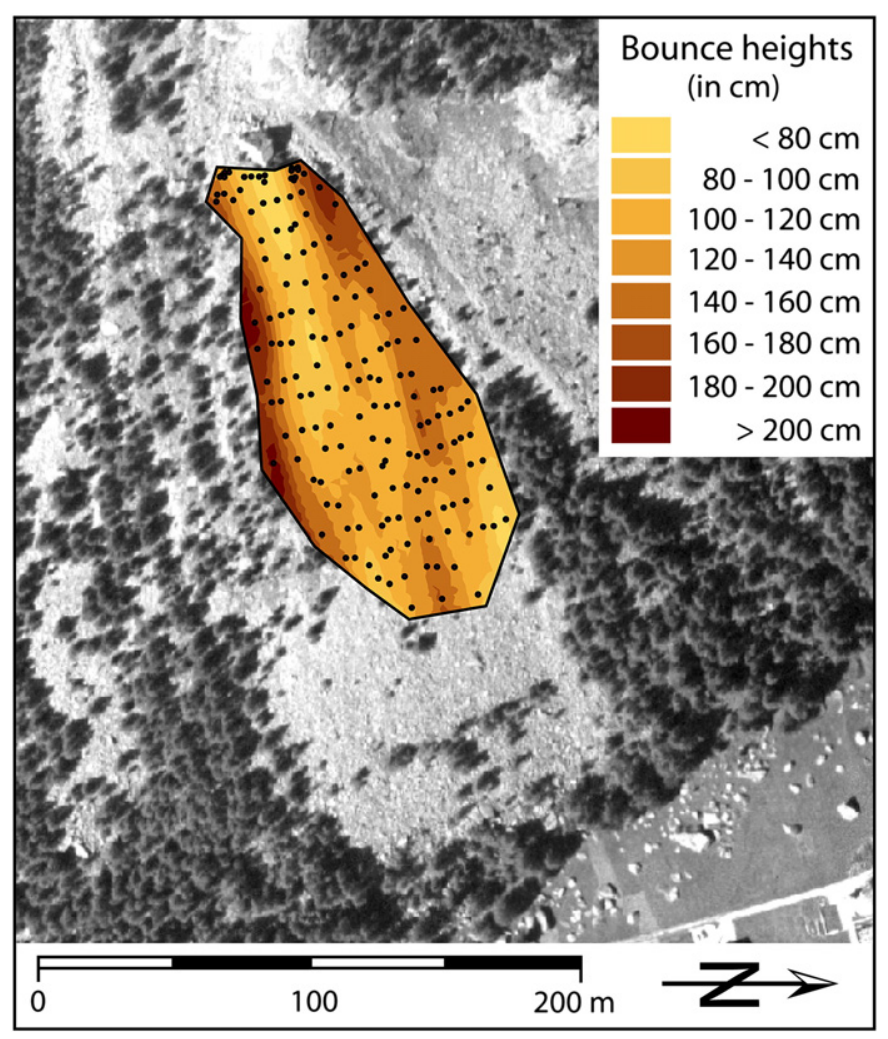

Fig. 5. Spatial distribution of maximum bounce heights. The big boulder identified in the uppermost part of the study site clearly alleviates bounce heights for the areas below. Highest values occur at the lateral boundaries (aerial photograph reproduced by courtesy of swisstopo (BA081119)). 


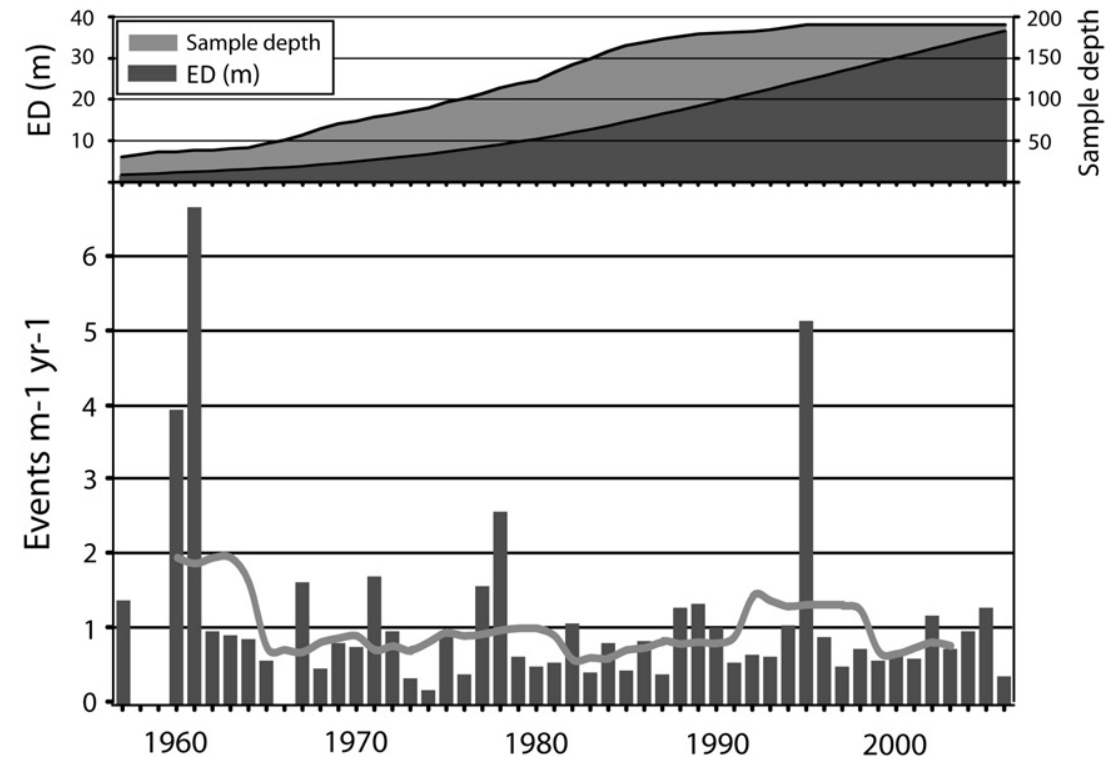

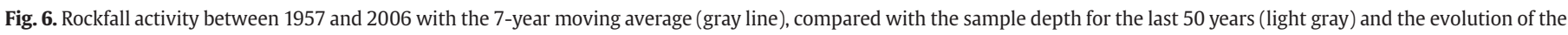
ED (total DBH, dark gray).

The reconstruction of tree ages and forest development was comprehensively confirmed by the visual analyses of the aerial photographs. Both methods reveal an afforestation that started in the central part at the lower levels of the study site and gradually moved farther up over the years. Based on the aerial photographs, apparently the reconstruction of rockfall activity over the last five decades appreciably corresponds with the time the forest stand has existed on the investigated slope. The photographs furthermore indicate that afforestation did not start at the study site exclusively but occurred on the entire slope (Fig. 8). The drastic change in the forest cover becomes very obvious when comparing the aerial picture of 1941 with that of 2004. In 1941 (Fig. 8A), the slope was bare and the current-day forest almost nonexistent; whereas in 2004 (Fig. 8B), the entire slope (1 ha in surface) was covered with dense forest. Possible explanations for this quite rapid and ubiquitous afforestation could be (i) a drastic decrease in rockfall activity with the subsequent stabilization of the slope or (ii) the overall increase in mean annual temperatures as documented by meteorological data (Bader and Kunz, 1998) leading to better growth conditions for trees after the 1940s. Based on the low-resolution data and supporting information, it is, however, impossible to draw further conclusions as to the changes in rockfall activity, the existence of years with largely increased rockfall rates, or for the evolution of the stand.

Apart from the large-scale changes in the forest cover, the comparison of the aerial photographs also allowed identification of interesting small-scale changes. Fig. 8C and D show an extract of the departure zones where, sometime between 1958 and 1968, a large block $\left(2000 \mathrm{~m}^{3}\right)$ travelled for $\sim 100 \mathrm{~m}$ from the frontal area of the departure zone to its current position at the uppermost limit of the study site. The aerial photographs also illustrate that the event completely destroyed the upcoming forest. Based on the tree-ring reconstructions and the increased rockfall activity in 1960 and 1961, we believe that the block was released during this period as rockfall increased.

The presence of this huge boulder does not only affect the trajectories of rockfall by deviating or stopping rocks, but it also provides a shielding effect for the areas located in the fall line farther down the slope. This protective effect may also explain the abundant appearance of a dense forest at the study site, whereas trees are still missing north of the investigated stand and only occur in the form of a much less dense forest stand to the south of the study site.
The forest stand analyzed in this study was quite young with an average age of 35.7 years, as compared to other dendrogeomorphic studies covering several centuries (Stoffel et al., 2005b; Perret et al., 2006). The recent age of the individuals, however, simplified the sampling and the visual analysis of the samples in the laboratory, as we could deal with comparably small trees showing relatively few tree rings. A young tree age furthermore reduces the occurrence of hidden injuries, as there was not enough time for a wound to heal completely

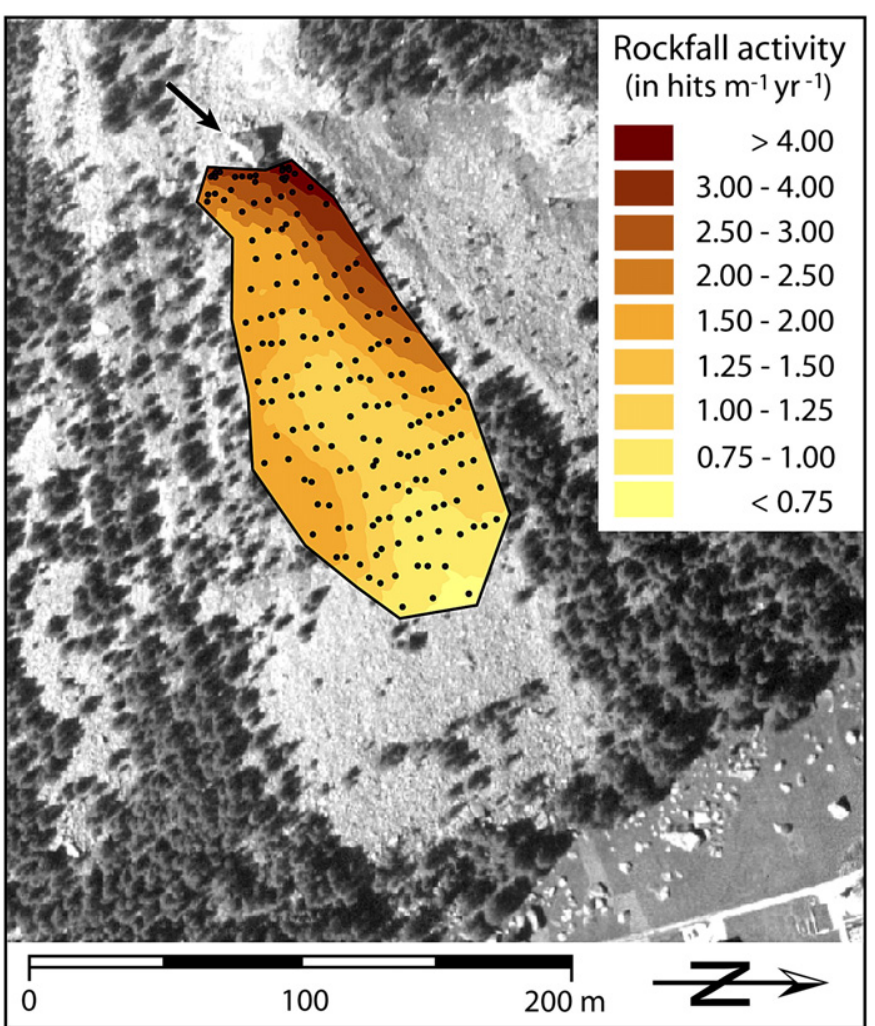

Fig. 7. Spatial distribution of rockfall activity. The highest activity is observed on the north-facing forest border, the lowest activity in the central part at the bottom of the study site. Notice the shielding effect of the big boulder (black arrow) at the upper end of the study site (aerial photograph reproduced by courtesy of swisstopo (BA081119)). 


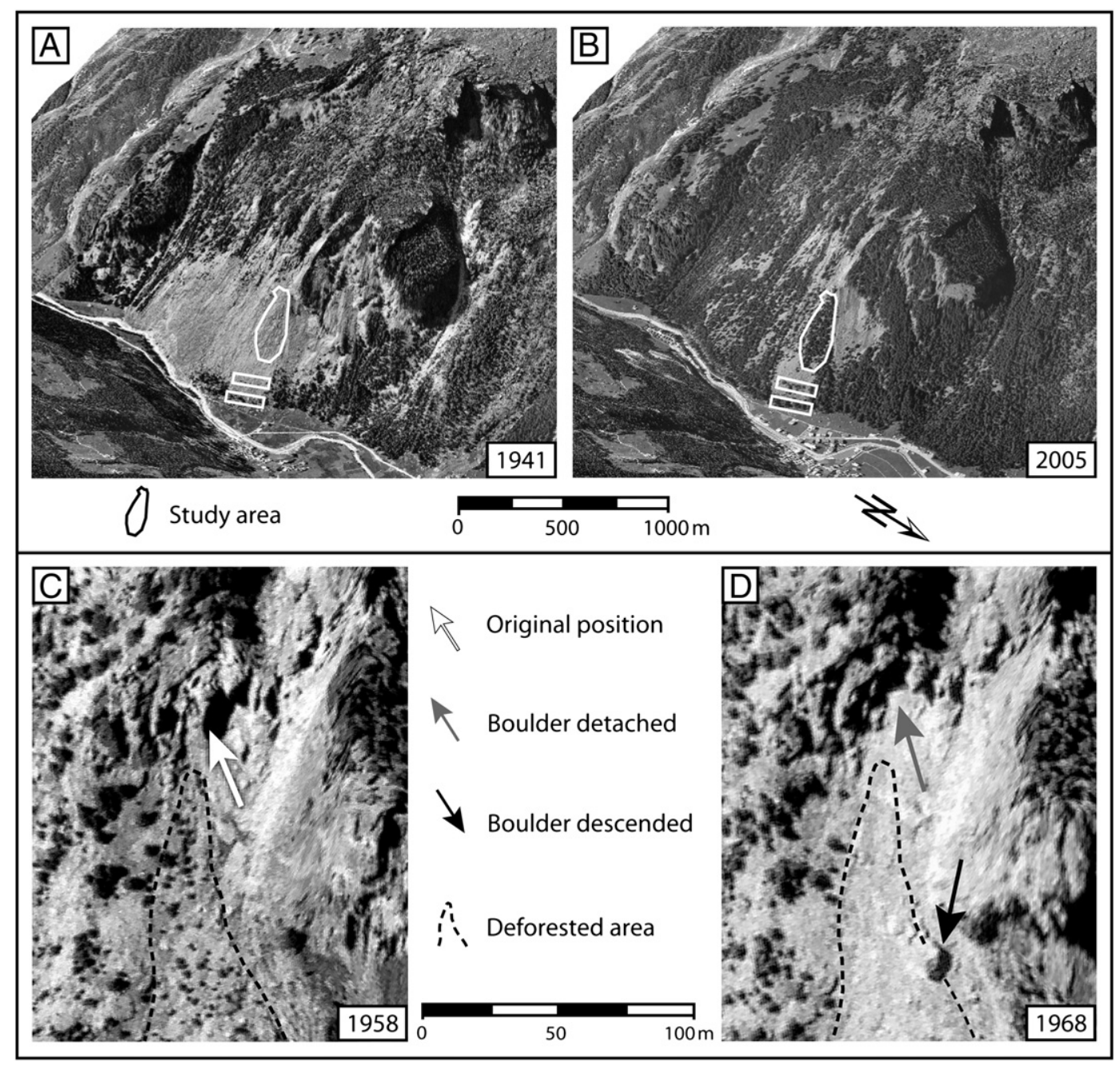

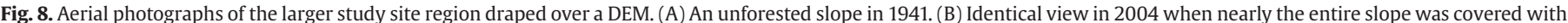

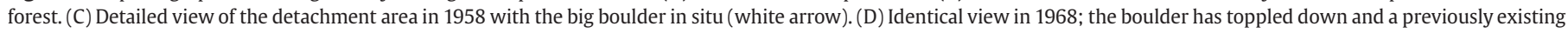
stand has been destroyed (aerial photographs reproduced by courtesy of swisstopo (BA081119)).

thus making the scar undetectable when inspecting the stem's exterior (Stoffel and Perret, 2006). As we reconstructed a large number of events for a period of only five decades, we could provide a very extensive and dense data set that allowed a more detailed analysis of changes, with a much higher resolution in time and space.

We should also mention that the reconstructed number of events at the site has to be seen as a minimum frequency, because of the nature of the process itself and the method used to study rockfall. A falling, bouncing, or rolling rock can traverse a forest without hitting any trees and thus leave no marks at all. In addition, we did not take into account potential multiple events occurring in the same tree in the same year, as the approach used in this study does not allow differentiation between a single rock leaving multiple scars on a tree and several rocks hitting a tree at different times of the year.

At a more methodological level, we note that reaction wood was only very rarely observed in the selected trees (13 samples; $0.6 \%$ ). In contrast to other mass movement processes (such as debris flows, snow avalanches, or landslides), rockfall does not seem to favor the formation of reaction wood resulting from the rock impact. It seems very likely that the energy transfer between the falling rock and the tree has to be seen as the main reason for this different reaction, as energy is transferred in the very short time span of only a fraction of a second, i.e., between 2 and $6 \times 10^{-3} \mathrm{~s}$ in the case of concrete walls (Rutz, 1999) and, moreover, concentrated at a single point of the tree's stem. Another reason for the scarce appearance of reaction wood is the sampling strategy. Most of the samples were taken with an increment borer, very close to each wound. As reaction wood generally occurs in the opposite direction of the injury, detection is unlikely in a position adjacent to it. However, this is no explanation for the low appearance rate of reaction wood in the cross sections, where reaction wood can be found only in $3 \%$ of the samples. It is also true that the young age of trees certainly favours the absence of reaction wood, as they maintain a certain flexibility, which allows them to bend laterally during collisions.

The assessment of past global rockfall activity was based on a "rate" that includes the DBH in order to counterbalance the effect of the increasingly larger target surface offered to individual rockfall fragments with time. Results are given with a yearly resolution and indicate a strong variability of activity over the years. On the one hand, a certain background rockfall activity is present during "normal" years attaining $0.5-1$ event $\mathrm{m}^{-1} \mathrm{y}^{-1}$. On the other hand, some pronounced event years exist with rockfall rates of more than 6 events $\mathrm{m}^{-1} \mathrm{y}^{-1}$. This variability can most probably be explained by variations of external factors, such as exceptional freeze-thaw cycles (Gardner, 1983; Matsuoka and Sakai, 1999; Matsuoka, 2006), the rising of mean annual temperatures (Davies et al., 2001), or extreme precipitation events (Schneuwly and Stoffel, 2008).

The analysis of the meteorological data for the 1995 event year revealed some extreme precipitation events before the onset of the vegetation period. The meteorological stations of Grächen $(8 \mathrm{~km}$ northwest of the study site) and Zermatt (20 km southwest) both 
recorded exceptional rainfall on 5 November 1994 with $67 \mathrm{~mm}$ and $94.4 \mathrm{~mm}$, respectively. Grächen started recording precipitation in 1959 and lists only five one-day precipitation events with more rainfall, whereas precipitation data of Zermatt shows only one event with more rainfall since the beginning of systematic recording in 1892. The local meteorological station in Saas Balen started recording in December 1994 and registered the second strongest precipitation $(89.8 \mathrm{~mm}$ ) event ever since at the 24. April 1995 (Schneuwly and Stoffel, 2008). It has to be mentioned that the meteorological conditions in this alpine region can significantly vary on a very local scale. Nevertheless, data shows two extreme rainfall events very close to the study site that could have caused (directly or indirectly) the exceptional rockfall activity recorded in the 1995 tree rings.

The outstanding rockfall activity in 1960/61 cannot be explained with exceptional precipitation events, as neither data from Grächen nor Zermatt indicate heavy rainfall events during the relevant period. In contrast, data from the Swiss Seismological Service note a magnitude 5.3 earthquake (Mercalli intensity VIII, $12 \mathrm{~km}$ depth) that would have occurred in Brig (18 km northeast of the study area) on 23 March 1960. There was no stronger earthquake in the Valais region ever since (ECOS, 2008) and we therefore believe that intense rockfall activity in 1960/61 would be the result of this seism.

The area with the highest rockfall activity is located in the north western sector of the study site. These results reflect the geomorphic situation in the field, as the most active area of the study site is located closest to the main source area of rockfall and does not have any trees farther above that could protect them. The generally lower rockfall rate at the southern boundary can be explained by the shielding effect of the big boulder located at the top of the stand and by the protection effect of trees located closer to the main rockfall source area. The least activity can be found at the very bottom of the study site, illustrating the substantial shielding effect of the trees growing farther above.

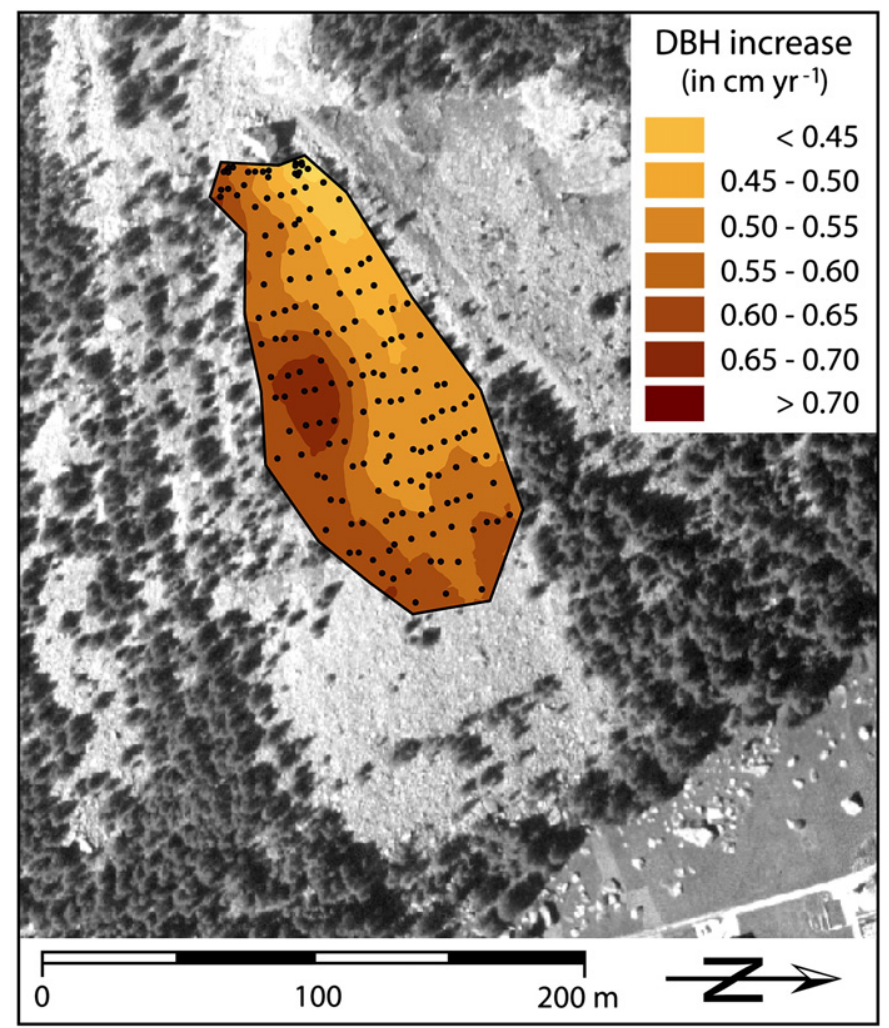

Fig. 9. Spatial analyses of the growing conditions using the yearly DBH increase as a reference. Worst growing conditions can be found in the areas with the most intense rockfall activity (aerial photograph reproduced by courtesy of swisstopo (BA081119)).
Finally, the yearly DBH increase was interpolated so as to obtain data on the growth conditions of trees on the study site. As a general rule, trees primarily increase their height in the first years before they increase their width (Kramer and Akça, 1995). At a certain stage, DBH increase will drop as a consequence of age. At the study site, tree growth is, in addition, disturbed by rockfall, which is why interpolated data (Fig. 9) neither individually reflect the age distribution nor the rockfall frequency, but rather indicate a mixture of both parameters. In the upper part of the study area, the interpolated yearly DBH increase nicely matches the pattern of the rockfall frequency (see Fig. 8). Growing conditions are the worst in the north western sector of the study site, and the DBH increase is apparently hampered by the very high rockfall activity. In the lower part of the main forest stand, both parameters seem to influence the conditions of growth: The largest DBH increase can be identified in a sector with rather a low rockfall activity and a moderate tree age.

\section{Conclusion}

Tree-ring analysis of 937 samples from nearly 200 trees allowed reconstruction of 755 rockfall events. The rather young mean age of only 36 years resulted in a dense data set that allowed detailed spatial analysis. Thus, spatial distribution of maximum bounce heights and rockfall activity could be assessed. While both of the methods used in the field and in the laboratory are relatively time consuming, they proved to be a powerful tool furnishing essential information about the past and present behavior of rockfall on a forested slope.

\section{Acknowledgement}

The authors would like to thank Dr. Michelle Bollschweiler for her assistance in the field and the laboratory, as well as Oliver Hitz for his helpful comments on wood anatomy. We are also grateful to Lautaro Correa for his exhausting support in the field and furthermore kindly acknowledge Moe Mynt for his intelligible instructions on the GIS. Finally, we would like to express our appreciation to the local administration and the forest warden, who always allowed us to work in their forest stand.

\section{References}

Azzoni, A., Barbera, G.L., Zaninetti, A., 1995. Analysis and prediction of rockfalls using a mathematical model. International J. Rock Mechanics and Mining Sci. 32, 709-724.

Bader, S., Kunz, P., 1998. Klimarisiken - Herausforderung für die Schweiz. Wissenschaftlicher Schlussbericht NFP31, VdF Hochschulverlag AG, Zürich. (In German).

Bearth, P., 1973. Geologischer Atlas der Schweiz 1:25000, Simplon (Atlasblatt 61). Schweizerische Geologische Kommission.

Bearth, P., 1980. Geologischer Atlas der Schweiz 1:25000, Niklaus (Atlasblatt 71). Schweizerische Geologische Kommission.

Berger, F., Quetel, C., Dorren, L.K.A., 2002. Forest: a natural protection mean against rockfall, but with which efficiency? The objectives and methodology of the ROCKFOR project. Interpraevent 2002, Band, 2, pp. 815-826.

Bollschweiler, M., Stoffel, M., Schneuwly, D.M., Bourqui, K., 2008. Traumatic resin ducts in Larix decidua stems impacted by debris flows. Tree Physiol. 28, 255-263.

Bozzolo, D., Pamini, R., Hutter, K., 1986. Rockfall analysis - a mathematical model and its test with field data. Proceedings of the 5th International Symposium on Landslides in Lausanne. Balkema, Rotterdam, The Netherlands, pp. 555-560.

Braam, R.R., Weiss, E.E.J., Burrough, P.A., 1987a. Spatial and temporal analysis of mass movement using dendrochronology. Catena 14, 573-584.

Braam, R.R., Weiss, E.E.J., Burrough, P.A., 1987b. Dendrogeomorphological analysis of mass movement: a technical note on the research method. Catena 14, 585-589.

Bräker, O.U., 2002. Measuring and data processing in tree-ring research - a methodological introduction. Dendrochronologia 20, 203-216.

Coe, J.A., Harp, E.L., 2007. Influence of tectonic folding on rockfall susceptibility. American Fork Canyon, Utah, USA. Natural Hazards and Earth System Sci. 7, 1-14.

Davies, M.C.R., Hamza, O., Harris, C., 2001. The effect of rise in mean annual temperature on the stability of rock slopes containing ice-filled discontinuities. Permafrost and Periglacial Processes 12 (1), 137-144.

Dorren, L.K.A., Berger, F., Putters, U.S., 2006. Real size experiments and 3D simulation of rockfall on forested and non-forested slopes. Natural Hazards and Earth System Sci. $6,145-153$.

Douglas, G.R., 1980. Magnitude frequency study of rockfall in Co. Antrim, N. Ireland. Earth Surface Processes 5 (2), 123-129.

ECOS, 2008. Earthquake Catalog of Switzerland. http://histserver.ethz.ch/intro_e.html. Erismann, T.H., 1986. Flowing, rolling, bouncing, sliding, synopsis of basic mechanisms. Acta Mechanica 64, 101-110. 
ESRI (Environmental Systems Research Institute), 2008a. ArcGIS. http://www.esri.com/ index.html.

ESRI (Environmental Systems Research Institute), 2008b. Geostatistical Analyst. http:// www.esri.com/software/arcgis/extensions/geostatistical/index.html.

Evans, S.G., Hungr, O., 1993. The assessment of rockfall hazard at the base of talus slopes. Canadian Geotechnical J. 30, 620-636.

Fantucci, R., Sorriso-Valvo, M., 1999. Dendrogeomorphological analysis of a slope near Lago Calabria (Italy). Geomorphology 30, 165-174.

Friedman, J.M., Vincent, K.R., Shafroth, P.B., 2005. Dating floodplain sediments using tree-ring response to burial. Earth Surface Processes and Landforms 30,1077-1091.

Harp, E.L., Wilson, R.C., 1995. Shaking intensity thresholds for rock falls and slides: Evidence from 1987 Whittier Narrows and Superstition Hills earthquake strongmotion records. Bulletin of the Seismological Soci. of America 85 (6), 1739-1757.

Hungr, O., Evans, S.G., 1988. Engineering evaluation of fragmental rockfall hazards. Proceedings of the 5th International Symposium on Landslides in Lausanne. The Netherlands, Balkema, Rotterdam, pp. 685-690.

Gardner, J.S., 1980. Frequency, magnitude, and spatial distribution of mountain rockfalls and rockslides in the Highwood Pass Area, Alberta, Canada. In: Coates, R., Vitek, J.D. (Eds.), Thresholds in Geomorphology. Allen and Unwin, New York, pp. 267-295.

Gardner, J.S., 1983. Rockfall frequency and distribution in the Highwood Pass area Canadian Rocky Mountains. Zeitschrift für Geomorphologie N.F. 27, 311-324.

Gruber, S., Hoelzle, M., Haeberli, W., 2004. Permafrost thaw and destabilization of Alpine rock walls in the hot summer of 2003. Geophyiscal Res. Lett. 31, L13504.

Guzzetti, F., Crosta, G., Detti, R., Agliardi, F., 2002. STONE: a computer program for the three-dimensional simulation of rock-falls. Computers and Geosci. 28 (9), 1079-1093.

Johnston, K., Ver Hoef, J.M., Krivoruchko, K., Lucas, N., 2003. Using ArcGIS Geostatistica Analyst. Environmental Systems Research Institute (ESRI). Redlands, CA, USA

Kirkby, M.J., Statham, I., 1975. Surface stone movement and scree formation. J. Geol. 83 , 349-362.

Kramer, H., Akça, A., 1995. Leitfaden zur Waldmesslehre. J.D. Sauerländers. Verlag, Frankfurt am Main, Germany. (In German).

Lafortune, M., Filion, L., Hétu, B., 1997. Dynamique d'un front forestier sur un talus d'éboulis actif en climat tempéré froid (Gaspésie, Québec). Géogr. Phys. Quat. 51 (1), 1-15 (In French).

Luckman, B.H., 1976. Rockfalls and rockfall inventory data; some observations from the Surprise Valley, Jasper National Park, Canada. Earth Surface Processes and Landforms 1, 287-298.

Luckman, B.H., Fiske, C.J., 1995. Estimating long-term rockfall accretion rates by lichenometry. In: Slaymaker, O. (Ed.), Steepland Geomorphology. Wiley, Chichester UK, pp. 233-255.

Marzorati, S., Luzi, L., De Amicis, M., 2002. Rock falls induced by earthquakes: a statistical approach. Soil Dynamics and Earthquake Engineering 22 (7), 565-577.

Matsuoka, N., 2006. Frost wedging and rockfalls on high mountain rock slopes: 11 years of observations in the Swiss Alps. Geophysical Res. Abstracts 8, 05344.

Matsuoka, N., Sakai, H., 1999. Rockfall activity from an alpine cliff during thawing periods. Geomorphology 28, 309-328.

McCarroll, D., Shakesby, R.A., Matthews, J.S., 1998. Spatial and temporal patterns of Late Holocene rockfall activity on a Norwegian talus slope: lichenometry and simulation-modelling approach. Arctic and Alpine Res. 30, 51-60.

Okura, Y., Kitahara, H., Sammori, T., Kawanami, A., 2000. The effects of rockfall volume on runout distance. Engineering Geol. 58 (2), 109-124.
Perret, S., Stoffel, M., Kienholz, H., 2006. Spatial and temporal rockfall activity in a forest stand in the Swiss Prealps - a dendrogeomorphological case study. Geomorphology $74,219-231$

Ritchie, A.M., 1963. Evaluation of rockfall and its control. Washington, DC: Highway Research Board, National Research Council, Highway Research Record, 17, pp. 13-28.

Ruppen, P.J., Imseng, G., Imseng, W., 1979. Saaser Chronik 1200-1979. Rotten-Verlag, Brig, Valais, Switzerland. (In German).

Rutz, J., 1999. Block-Anprall auf Stahlbetonwände aus Steinschlägen, Lawinen, Murgängen und Überschwemmungen. Gebäudeversicherungsanstalt des Kantons. St. Gallen, Sankt Gallen, Switzerland. (In German).

Sass, O., 2005. Temporal variability of rockfall in the Bavarian Alps, Germany. Arctic, Antarctic, and Alpine Res. 37 (4), 564-573.

Schneuwly, D.M., Stoffel, M., 2008. Tree-ring based reconstruction of the seasonal timing, major events and origin of rockfall on a case-study slope in the Swiss Alps. Natural Hazards and Earth System Sci. 8, 203-211.

Schweingruber, F.H., 1996. Tree Rings and Environment. Dendroecology, Paul Haupt, Bern, Switzerland.

Schweingruber, F.H., 2001. Holzanatomie. Paul Haupt, Bern, Switzerland. (In German) Shroder Jr., J.F., 1978. Dendrogeomorphologic analysis of mass movement on Table Cliffs Plateau, Utah. Quaternary Res. 9, 168-185.

Shroder Jr., J.F., 1980. Dendrogeomorphology: review and new techniques of tree-ring dating. Progress in Physical Geography 4, 161-188.

Solomina, O.N., 2002. Dendrogeomorphology: research requirements. Dendrochronologia 20 (1), 231-243.

Statham, I., Francis, S.C., 1986. Influence of scree accumulation and weathering on the development of steep mountain slopes. In: Abrahams, A.D. (Ed.), Hillslope Processes. Winchester, Allen and Unwin Inc., Sydney, NSW, Australia, pp. 245-267.

Stoffel, M., in press. Dating past geomorphic processes with tangential rows of traumatic resin ducts. Dendrochronologia.

Stoffel, M., Perret, S., 2006. Reconstructing past rockfall activity with tree rings: some methodological considerations. Dendrochronologia 24 (1), 1-15.

Stoffel, M., Lièvre, I., Monbaron, M., Perret, S., 2005a. Seasonal timing of rockfall activity on a forested slope at Täschgufer (Valais, Swiss Alps) - a dendrochronological approach. Zeitschrift für Geomorphologie 49 (1), 89-106.

Stoffel, M., Schneuwly, D., Bollschweiler, M., Lièvre, I., Delaloye, R., Myint, M., Monbaron, M., 2005b. Analyzing rockfall activity (1600-2002) in a protection forest - a case study using dendrogeomorphology. Geomorphology 68 (3-4), 224-241.

Stoffel, M., Wehrli, A., Kühne, R., Dorren, L.K.A., Perret, S., Kienholz, H., 2006. Assessing the protective effect of mountain forests against rockfall using a 3D simulation model. Forest Ecol. Management 225, 113-122.

Stokes, M.A., Smiley, T.L., 1968. An Introduction to Tree-ring Dating. University of Chicago Press, Chicago., IL, USA.

Strunk, H., 1997. Dating of geomorphological processes using dendrogeomorphological methods. Catena 31,137-151.

Wiles, G.C., Calkin, P.E., Jacoby, G.C., 1996. Tree-ring analysis and Quaternary geology: principles and recent applications. Geomorphology 16, 259-272.

Zinggeler, A., 1989. Steinschlagsimulation in Gebirgswäldern. Modellierung der relevanten Teilprozesse. Diploma thesis, Geografisches Institut, Univeristät Bern, Bern, Switzerland. (In German). 